\title{
Jenis dan Jumlah Mikroorganisme Aerob pada Persalinan Spontan Kurang dan Cukup Bulan tanpa Ketuban Pecah Dini
}

\author{
Yan O'Neil S. Meliala, ${ }^{1}$ Sofie Rifayani Krisnadi, ${ }^{2} \mathrm{Jusuf}^{\prime}$ Sulaeman Effendi ${ }^{2}$ \\ ${ }^{1}$ Rumah Sakit Kamulyan Kuningan ${ }^{2}$ Departemen Obstetri dan Ginekologi \\ Fakultas Kedokteran Universitas Padjadjaran-Rumah Sakit Dr. Hasan Sadikin Bandung
}

\begin{abstract}
Abstrak
Persalinan kurang bulan merupakan penyebab utama mortalitas dan morbiditas perinatal. Angka kejadian persalinan kurang bulan yang disebabkan infeksi sebesar 40-50\%. Tujuan penelitian ini untuk membuktikan bahwa persalinan spontan kurang bulan tanpa ketuban pecah dini didahului oleh korioamnionitis serta mengetahui perbandingan jenis dan jumlah mikroorganisme aerob penyebab korioamnionitis pada persalinan spontan kurang dan cukup bulan tanpa ketuban pecah dini. Penelitian ini merupakan studi komparatif dengan rancangan studi silang (cross sectional). Penelitian ini dilakukan di Rumah Sakit Dr. Hasan Sadikin Bandung dan rumah sakit jejaringnya periode Juli-Agustus 2009 dengan subjek penelitian sebanyak 53 penderita. Analisis data dengan uji statistik digunakan uji chi-kuadrat dan untuk membandingkan perbedaan dua usia persalinan rata-rata digunakan uji beda (uji t). Kemaknaan ditentukan berdasarkan nilai $\mathrm{p}<0,05$. Tidak terdapat perbedaan karateristik penderita pada kedua kelompok subjek penelitian. Terdapat hubungan bermakna kedua kelompok dengan korioamnionitis $(\mathrm{p}=0,004)$, terdapat perbedaan bermakna jenis mikroorganisme aerob antara kedua kelompok $(\mathrm{p}=0,025)$, dan terdapat perbedaan bermakna jumlah mikroorganisme aerob antara kedua kelompok $(\mathrm{p}=0,003)$. Simpulan, persalinan spontan kurang bulan tanpa ketuban pecah dini disebabkan korioamnionitis dan jumlah mikroorganisme mempengaruhi kejadian persalinan spontan kurang bulan tanpa ketuban pecah dini. [MKB. 2012;44(1):44-9].
\end{abstract}

Kata kunci: Korioamnionitis, mikroorganisme aerob, persalinan spontan kurang bulan tanpa ketuban pecah dini

\section{Species and Number of Aerob Microorganism in Preterm and Term Spontaneous Delivery with Intact Membrane}

\begin{abstract}
Preterm birth is the main cause of perinatal mortality and morbidity. Prevalence of preterm delivery which is caused by infection is $40-50 \%$. The aim of this study was to determine that spontaneous preterm delivery without premature rupture of the membrane is initiated by chorioamnionitis and to find out the comparison of aerob microorganism species and number from spontaneous preterm and term delivery without premature rupture of the membrane. This was a comparative cross sectional study. This study was conducted in Dr. Hasan Sadikin Hospital Bandung and satelite hospital, from July to August 2009, the subjects were 53 patients. This study analyzed with chi-square and t-test to differentiate average of gestational age with $p<0.05$. There's no significant difference of characteristic between two research subject groups, significant difference between two research subject groups with chorioamnionitis $(\mathrm{p}=0.004)$, significant difference of aerob microorganism species between two research subject groups $(\mathrm{p}=0.025)$ and significant difference number of aerob microorganism between two research subjects $(\mathrm{p}=0.003)$. In conclusions, chorioamnionitis can initiate a spontaneous preterm delivery without premature rupture of the membrane and the number of microorganism indicated the virulence of microorganism that caused chorioamnionitis which is initiated spontaneous preterm delivery without premature rupture. [MKB. 2012;44(1):44-9].
\end{abstract}

Key words: Aerob microorganism, chorioamnionitis, spontaneous preterm delivery without premature rupture of the membrane

Korespondensi: Yan O'Neil S. Meliala, dr., Sp.OG, Rumah Sakit Kamulyan, jalan Raya Cigugur 28 Cigugur, Kuningan Jawa Barat 45552, telepon (0232) 873206, faks (0232) 875516, mobile 0811246039, e-mail oneil_meliala@yahoo.com 


\section{Pendahuluan}

Persalinan kurang bulan merupakan masalah di bidang obstetrik dan perinatologi yang berhubungan dengan tingginya angka morbiditas dan mortalitas bayi. Tujuh puluh persen morbiditas dan mortalitas neonatus disebabkan oleh prematuritas. Lebih dari $65 \%$ kematian neonatus terjadi pada bayi yang lahir prematur, dengan angka kematian sebesar 19.000 per tahunnya. ${ }^{1,2}$

Kejadian persalinan kurang bulan di Indonesia berkisar 10-20\% dan di Rumah Sakit Dr. Hasan Sadikin Bandung 8,2\% dari seluruh persalinan pada periode Januari 1998 sampai Desember 2000, dengan angka kematian perinatal sebesar $53,6 \%$. ${ }^{3}$ Insidensinya cenderung meningkat dalam beberapa tahun terakhir, tetapi angkanya cenderung konstan pada persalinan dengan usia kehamilan kurang dari 32 minggu, yaitu sebesar $1-2 \%$. Lockwood $^{4}$ mengemukakan bahwa persalinan kurang bulan dapat terjadi melalui proses aktivasi hypothalamic-pituitary-adrenal axis dari janin dan ibu, proses infeksi, perdarahan desidua, dan peregangan uterus yang patologis. Infeksi dapat menyebabkan persalinan kurang bulan dengan cara mikroorganisme penyebab infeksi akan menembus barier serviks sebelum memicu perubahan pada selaput amnion dan struktur segmen bawah rahim. Setelah melewati barier serviks mikroorganisme akan menginisiasi persalinan melalui beberapa cara yang selanjutnya akan menstimulasi produksi prostaglandin dan pelepasan beberapa mediator imun yang akan menstimulasi kontraksi sel-sel otot polos. ${ }^{5}$ Cara lainnya yaitu efek pelepasan toksin bakteri yang akan menginisiasi terjadinya proses inflamasi pada desidua dan korioamnion. Toksin tersebut akan secara langsung menstimulasi sintesis prostaglandin pada amnion dan korion serta melepaskan mediator inflamasi dari sel desidua yang dapat langsung menstimulasi sel miometrium, dan protease yang dihasilkan mampu merusak selaput membran. Jika selaput membran rusak maka akan terjadi proses pemicu timbulnya persalinan. $^{6}$

Korioamnionitis sebagai salah satu penyebab persalinan kurang bulan, ${ }^{7}$ kemudian Ustun $\mathrm{dkk} .{ }^{8}$ menemukan angka kejadian inflamasi chorionic plate pada persalinan kurang bulan sebanyak $35,5 \%$, sedangkan persalinan cukup bulan hanya 5,4\%.Di Rumah Sakit Dr. Hasan Sadikin Bandung, Krisnadi ${ }^{6}$ menyimpulkan bahwa korioamnionitis berhubungan dengan kejadian persalinan kurang bulan. Onderdonk dkk. ${ }^{9}$ menyimpulkan bahwa persalinan kurang bulan dapat terjadi apabila terdapat mikroorganisme patogen dengan jumlah yang cukup dan dapat diperkirakan dengan menghitung jumlah mikroorganisme sebagai skrining.
Peneliti tertarik untuk membuktikan bahwa pada persalinan kurang bulan tanpa ketuban pecah dini didahului oleh korioamnionitis, serta mengetahui jenis dan jumlah mikroorganisme yang terdapat pada selaput amnion dari ibu yang mengalami persalinan kurang dan cukup bulan tanpa ketuban pecah dini.

\section{Metode}

Penelitian ini merupakan studi komparatif dengan rancangan studi potong lintang membandingkan hasil kultur selaput amnion pada persalinan spontan kurang dan cukup bulan tanpa ketuban pecah dini terhadap 53 penderita yang akan melahirkan serta memenuhi kriteria inklusi dan bersedia mengikuti penelitian setelah mendapatkan penjelasan dan menandatangani persetujuan (informed consent). Kriteria inklusi yaitu wanita hamil tunggal hidup dengan usia kehamilan 21-36 minggu yang mengalami persalinan spontan kurang bulan tanpa ketuban pecah dini (kelompok kasus) dan wanita hamil tunggal hidup dengan usia kehamilan 37-42 minggu yang mengalami persalinan cukup bulan tanpa ketuban pecah dini (kelompok kontrol).

Besar sampel ditentukan berdasarkan formula uji hipotesis dua proporsi didapatkan minimal sampel 50 orang. Pengambilan sampel diperoleh dari kamar bersalin Departemen Obstetri \& Ginekologi Rumah Sakit Dr. Hasan Sadikin Bandung dan rumah sakit jejaringnya hingga jumlah sampel terpenuhi periode Juli-Agustus 2009.

Pengambilan sampel dilakukan setelah bayi lahir. Setelah bayi lahir dan pengeluaran sisa cairan ketuban, peralatan dipersiapkan, yaitu berupa kain alas steril, gunting steril, kassa steril, serta tabung penyimpanan dan pengiriman sampel. Kain alas steril diletakkan di bawah bokong ibu dan plasenta siap dilahirkan. Pada saat plasenta dilahirkan, plasenta kemudian diletakkan di atas kain steril dan selaput amnion yang terakhir keluar diambil menggunakan kassa steril dan dipotong dengan ukuran 2x2 cm digunting menggunakan gunting steril dan kemudian dimasukkan ke dalam tabung steril dan siap dikirimkan ke laboratorium.

Selanjutnya dilakukan pemeriksaaan kultur mikroorganisme di Laboratorium Prodia dari bahan pemeriksaan selaput amnion yang diambil untuk mengetahui jenis dan jumlah mikroorganisme aerob.

Analisis data menggunakan uji $\mathrm{X}^{2}$ untuk menguji perbedaan dua buah proporsi atau untuk membandingkan perbedaan dua kelompok data, selain itu digunakan pula uji $t$ untuk membandingkan perbedaan dua rata-rata untuk data kuantitatif berdistribusi normal. Kemaknaan hasil uji ditentukan berdasarkan nilai $\mathrm{p} \leq 0,05$. 


\section{Hasil}

Agar kelompok penelitian dapat diperbandingkan, maka diambil persamaan karakteristik kedua kelompok tersebut yang meliputi usia, tingkat pendidikan, status pekerjaan, status sosial, paritas, kunjungan kontrol kehamilan, dan pemeriksaan hemoglobin $(\mathrm{Hb})$, leukosit, trombosit, hematokrit, dan kultur mikroorganisme.

Sebagian besar ibu hamil dengan persalinan spontan kurang bulan tanpa ketuban pecah dini pada kelompok usia 21-25 tahun terdapat sejumlah 16 orang, begitu pula persalinan cukup bulan tanpa ketuban pecah dini sebagian besar pada kelompok usia 21-25 tahun terdapat sejumlah 16 orang. Hasil analisis uji chi-kuadrat menunjukkan bahwa tidak terdapat perbedaan karakteristik ibu hamil dengan persalinan spontan kurang dan cukup bulan tanpa ketuban pecah dini berdasarkan usia dengan nilai $\mathrm{p}=0,063$. Sebagian besar ibu hamil dengan persalinan spontan kurang bulan tanpa ketuban pecah dini dengan pendidikan SMP dan SMA masing-masing 10 orang, begitu pula persalinan cukup bulan tanpa ketuban pecah dini sebagian besar dengan pendidikan SMP sejumlah 13 orang dan hasil analisis uji chi-kuadrat menunjukkan tidak terdapat perbedaan dengan nilai $\mathrm{p}=0,485$ (Tabel 1).

Semua ibu hamil dengan persalinan spontan kurang bulan tanpa ketuban pecah dini sebagai ibu rumah tangga dan ibu hamil dengan persalinan cukup bulan tanpa ketuban pecah dini juga lebih banyak sebagai ibu rumah tangga (23/25 orang). Hasil analisis uji chi-kuadrat menunjukkan bahwa tidak terdapat perbedaan dengan nilai $\mathrm{p}=0,079$ (Tabel 1).

Tidak terdapat perbedaan karakteristik ibu hamil dengan persalinan spontan kurang dan

Tabel 1 Karakteristik Subjek Penelitian berdasarkan Identitas Penderita

\begin{tabular}{|c|c|c|c|c|c|}
\hline \multirow{3}{*}{$\begin{array}{r}\begin{array}{r}\text { Identitas } \\
\text { Penderita }\end{array} \\
\text { Usia (tahun) }\end{array}$} & \multicolumn{3}{|c|}{ Persalinan } & \multirow{2}{*}{\multicolumn{2}{|c|}{ Kemaknaan }} \\
\hline & $\begin{array}{c}\text { Cukup Bulan } \\
(n=25)\end{array}$ & $\begin{array}{c}\text { Kurang Bulan } \\
(n=28)\end{array}$ & $\begin{array}{c}\text { Total } \\
(n=53)\end{array}$ & & \\
\hline & & & & $\mathrm{x}^{2}=7,387$ & $\mathrm{p}=0,063$ \\
\hline$<20$ & 1 & 8 & 9 & & \\
\hline $21-25$ & 16 & 16 & 32 & & \\
\hline $26-30$ & 8 & 4 & 12 & & \\
\hline Mean (SD) & $23,44(2,69)$ & $21,86(3,29)$ & $22,60(3,10)$ & & \\
\hline Pendidikan & & & & $x^{2}=1,448$ & $\mathrm{p}=0,485$ \\
\hline $\mathrm{SD}$ & 5 & 8 & 13 & & \\
\hline SMP & 13 & 10 & 23 & & \\
\hline SMA & 7 & 10 & 17 & & \\
\hline Pekerjaan & & & & $x^{2}=3,094$ & $\mathrm{p}=0,079$ \\
\hline IRT & 23 & 28 & 51 & & \\
\hline Buruh & 2 & 0 & 2 & & \\
\hline Paritas & & & & $x^{2}=3,442$ & $\mathrm{p}=0,179$ \\
\hline 0 & 9 & 17 & 26 & & \\
\hline 1 & 12 & 9 & 21 & & \\
\hline 2 & 4 & 2 & 6 & & \\
\hline $\mathrm{PNC}$ & & & & $\mathrm{t}_{\text {hitung }}=4,449$ & $\mathrm{P}<0,001$ \\
\hline Mean (SD) & $7,44(2,18)$ & $5,14(1,55)$ & $6,23(2,18)$ & & \\
\hline
\end{tabular}

Keterangan: $\mathrm{x}^{2}=$ uji chi-kuadrat, $\mathrm{t}=$ uji $\mathrm{t}$ untuk data tidak berpasangan, $\mathrm{p}=$ nilai kemaknaan dihitung berdasarkan uji chi-kuadrat, IRT=ibu rumah tangga

Tabel 2 Hasil Pemeriksaan Komponen Darah pada Kelompok Persalinan Spontan Kurang dan Cukup Bulan tanpa Ketuban Pecah Dini

\begin{tabular}{ccccccc}
\hline \multirow{2}{*}{ Variabel } & \multicolumn{3}{c}{ Persalinan } & \multicolumn{2}{c}{ Kemaknaan } \\
\cline { 2 - 4 } & $\begin{array}{c}\text { Cukup Bulan } \\
\text { Mean (SD) }\end{array}$ & $\begin{array}{c}\text { Kurang Bulan } \\
\text { Mean }(\text { SD) }\end{array}$ & $\begin{array}{c}\text { Total } \\
\text { Mean }(\text { SD) }\end{array}$ & & \\
\hline Hb & $11,72(1,06)$ & $11,44(1,13)$ & $11,57(1,10)$ & $\mathrm{t}_{\text {hitung }}=0,914$ & $\mathrm{p}=0,365$ \\
Leukosit & $11.572(2.665)$ & $15.078(6.838)$ & $13.424(12.394)$ & $\mathrm{t}_{\text {hitung }}=1,029$ & $\mathrm{p}=0,308$ \\
Trombosit & $252.680(54.015)$ & $221.250(29.874)$ & $236.075(45.397)$ & $\mathrm{t}_{\text {hitung }}=2,659$ & $\mathrm{p}=0,010$ \\
Hematokrit & $34,16(3,05)$ & $34,18(3,48)$ & $34,17(3,25)$ & $\mathrm{t}_{\text {bitung }}=-0,021$ & $\mathrm{p}=0,984$ \\
\hline
\end{tabular}

Keterangan: $\mathrm{t}=$ uji $\mathrm{t}$ untuk data tidak berpasangan, $\mathrm{p}=$ nilai kemaknaan dihitung berdasarkan uji $\mathrm{t}$ 
Yan O'Neil S. Meliala: Jenis dan Jumlah Mikroorganisme Aerob pada Persalinan Spontan Kurang Bulan dan Cukup Bulan

Tabel 3 Hubungan Persalinan Spontan Kurang Bulan dan Cukup Bulan tanpa Ketuban Pecah Dini dengan Korioamnionitis

\begin{tabular}{|c|c|c|c|c|c|}
\hline \multirow[b]{2}{*}{ Korioamnionitis } & \multicolumn{3}{|c|}{ Persalinan } & \multirow{2}{*}{\multicolumn{2}{|c|}{ Kemaknaan }} \\
\hline & $\begin{array}{c}\text { Cukup Bulan } \\
(n=25)\end{array}$ & $\begin{array}{c}\text { Kurang Bulan } \\
(n=28)\end{array}$ & $\begin{array}{c}\text { Total } \\
(n=53)\end{array}$ & & \\
\hline Positif & 7 & 19 & $26(49 \%)$ & $x^{2}=8,396$ & $\mathrm{p}=0,004$ \\
\hline Tidak & 18 & 9 & $27 \quad(51 \%)$ & & \\
\hline Total & 25 & 28 & $53(100 \%)$ & & \\
\hline
\end{tabular}

Tabel 4 Perbedaan Jenis Mikroorganisme Aerob pada Korioamnionitis antara Persalinan Spontan Kurang dan Cukup Bulan tanpa Ketuban Pecah Dini

\begin{tabular}{|c|c|c|c|c|}
\hline \multirow[b]{2}{*}{$\begin{array}{c}\text { Jenis Mikroorganisme Aerob pada } \\
\text { Korioamnionitis }\end{array}$} & \multicolumn{3}{|c|}{ Persalinan tanpa Ketuban Pecah Dini } & \multirow[b]{2}{*}{ Kemaknaan } \\
\hline & $\begin{array}{c}\text { Cukup } \\
\text { Bulan } \\
\text { n }\end{array}$ & $\begin{array}{c}\text { Kurang } \\
\text { Bulan } \\
\text { n }\end{array}$ & $\begin{array}{c}\text { Total } \\
\text { n }\end{array}$ & \\
\hline Staphylococcus sp. & 2 & 5 & 7 & \multirow{8}{*}{$\begin{aligned} x^{2} & =23,343 \\
p & =0,025\end{aligned}$} \\
\hline Pseudomonas sp. & 1 & 5 & 6 & \\
\hline Bacillus sp. & 0 & 2 & 2 & \\
\hline Streptococcus hemolyticus, Micrococcus sp. & 1 & 1 & 2 & \\
\hline Corynebacterium sp. & 1 & 4 & 5 & \\
\hline Enterobacter cloacae & 0 & 2 & 2 & \\
\hline Escherichia coli & 2 & 0 & 2 & \\
\hline Negatif & 18 & 9 & 27 & \\
\hline
\end{tabular}

Keterangan: $\mathrm{x}^{2}=$ uji chi-kuadrat, $\mathrm{p}=$ nilai kemaknaan dihitung berdasarkan uji chi-kuadrat

cukup bulan tanpa ketuban pecah dini berdasarkan paritas dengan nilai $\mathrm{p}=0,179$ (Tabel 1).

Tidak terdapat perbedaan karakteristik antara ibu hamil dengan persalinan spontan kurang dan cukup bulan tanpa ketuban pecah dini berdasarkan pre natal care (PNC) dengan nilai $\mathrm{p}<0,001$ (Tabel 1).

Hasil analisis independent $t$ test menunjukkan bahwa tidak terdapat perbedaan bermakna antara ibu hamil dengan persalinan spontan kurang bulan dibandingkan dengan persalinan cukup bulan tanpa ketuban pecah dini berdasarkan hasil pemeriksaan kadar $\mathrm{Hb}$, leukosit, dan hematokrit $(\mathrm{p}>0,05)$, sedangkan berdasarkan pemeriksaan trombosit berbeda secara bermakna dengan nilai $\mathrm{p}=0,010$ (Tabel 2).

Kejadian korioamnionitis lebih banyak terjadi pada ibu hamil dengan persalinan spontan kurang bulan dibandingkan dengan persalinan cukup bulan spontan tanpa ketuban pecah dini dan hasil analisis uji chi-kuadrat pada derajat kepercayaan 95\% dengan nilai $\mathrm{p}=0,004$ (Tabel 3).

Korioamnionitis lebih banyak disebabkan oleh mikroorganisme Staphylococcus sp. dan
Pseudomonas sp. masing-masing 5/9 penderita pada ibu hamil dengan persalinan spontan kurang bulan dan cukup bulan tanpa ketuban pecah dini. Jenis mikroorganisme pada persalinan cukup bulan tanpa ketuban pecah dini paling banyak Staphylococcus sp. dan E. coli masingmasing 2/9 penderita. Hasil analisis uji chikuadrat menunjukkan terdapat perbedaan jenis mikroorganisme aerob antara persalinan spontan kurang dan cukup bulan tanpa ketuban pecah dini dengan nilai $\mathrm{p}=0,025$ (Tabel 4).

Jumlah mikroorganisme aerob persalinan spontan kurang dan cukup bulan tanpa ketuban pecah dini mempunyai mean (SD) masingmasing 568,8 $(149,5)$ dan 5.195,0 $(725,4)$ dengan kemaknaan $\mathrm{t}_{\text {hitung }}=-3,127 ; \mathrm{p}=0,003$.

\section{Pembahasan}

Penyebab persalinan kurang bulan adalah multifaktor., ${ }^{1,6}$ Sekitar 25\% persalinan kurang bulan disebabkan oleh faktor ibu, di antaranya usia ibu saat hamil $<18$ tahun atau $>40$ tahun, status ekonomi yang rendah, kebiasaan merokok, dan nutrisi yang buruk. 
Dari hasil penelitian, terlihat bahwa sebagian besar ibu hamil dengan persalinan spontan kurang bulan tanpa ketuban pecah dini pada kelompok usia 21-25 tahun terdapat 16 orang, begitu pula persalinan cukup bulan tanpa ketuban pecah dini sebagian besar pada kelompok usia tersebut sejumlah 16 orang. Hasil analisis memperlihatkan tidak terdapat perbedaan karakteristik ibu hamil dengan persalinan spontan kurang bulan dibandingkan dengan persalinan cukup bulan tanpa ketuban pecah dini berdasarkan usia. Dibandingkan dengan yang didapatkan pada literatur bahwa faktor risiko terjadinya persalinan kurang bulan yaitu usia ibu $<18$ tahun dan $>40$ tahun, tidak terbukti pada penelitian ini karena persalinan spontan kurang bulan tanpa ketuban pecah dini terbanyak terdapat pada kelompok usia 21-25 tahun, yaitu sejumlah 16 orang., ${ }^{2,3,10-12}$

Hasil analisis berdasarkan pendidikan tidak terdapat perbedaan antara ibu hamil dengan persalinan spontan kurang dan cukup bulan tanpa ketuban pecah dini.

Semua ibu hamil dengan persalinan spontan kurang dan cukup bulan tanpa ketuban pecah dini lebih banyak sebagai ibu rumah tangga, tetapi tidak terdapat perbedaan pekerjaan ibu hamil dengan persalinan spontan kurang dan cukup bulan tanpa ketuban pecah dini. Tidak terdapat perbedaan paritas ibu hamil dengan persalinan spontan kurang dan cukup bulan tanpa ketuban pecah dini.

Berdasarkan penjelasan di atas, variabel usia, pendidikan, pekerjaan, dan paritas tidak berbeda antara kedua kelompok penelitian. Keadaan ini berbeda dengan literatur bahwa pendidikan yang rendah dan pekerjaan merupakan faktor risiko terjadinya persalinan kurang bulan. , $, 3,10,11,13,14^{2}$

Pre natal care rata-rata ibu hamil dengan persalinan spontan kurang bulan lebih jarang dibandingkan dengan ibu hamil dengan persalinan cukup bulan tanpa ketuban pecah dini (Tabel 2). Hasil analisis berdasarkan PNC ibu hamil terdapat perbedaan antara persalinan spontan kurang bulan dan persalinan cukup bulan tanpa ketuban pecah dini dengan nilai $p<0,001$. Hasil ini tidak dapat digunakan untuk menggambarkan bahwa pada PNC yang kurang dapat menyebabkan persalinan spontan kurang bulan tanpa ketuban pecah dini, karena PNC seharusnya dilakukan hingga ibu hamil mencapai usia kehamilan cukup bulan. Hal ini disadari sebagai salah satu kelemahan pada penelitian ini karena PNC pada kedua subjek penelitian tidak dilakukan sejak awal kehamilan.

Tidak terdapat perbedaan bermakna kadar $\mathrm{Hb}$, leukosit, dan hematokrit ibu hamil antara persalinan spontan kurang dan cukup bulan tanpa ketuban pecah dini, sedangkan berdasarkan jumlah trombosit terdapat perbedaan bermakna (Tabel 2).
Belum ditemukan hubungan langsung kejadian persalinan spontan kurang bulan pecah dini dengan jumlah trombosit, tetapi beberapa kasus dilaporkan terdapat perbedaan jumah trombosit yang bermakna pada persalinan spontan kurang bulan tanpa ketuban pecah dini disertai penyakit hipertensi dalam kehamilan.,12-16

Kejadian korioamnionitis lebih banyak terjadi pada ibu hamil dengan persalinan spontan kurang bulan dibandingkan dengan ibu hamil dengan persalinan cukup bulan tanpa ketuban pecah dini. Hasil analisis menunjukkan hubungan bermakna. Hasil penelitian ini sesuai dengan pernyataan Hillier $^{16}$ bahwa korioamnionitis menyebabkan persalinan kurang bulan, kemudian didukung oleh Hershkovits dkk. ${ }^{7}$ yang juga meneliti bahwa pada persalinan kurang bulan ditemukan lebih banyak kejadian korioamnionitis, dan juga sesuai dengan penelitian Krisnadi ${ }^{6}$ di Rumah Sakit Dr. Hasan Sadikin Bandung.

Mikroorganisme Staphylococcus sp. dan Pseudomonas sp. lebih banyak ditemukan pada korioamnionitis ibu hamil dengan persalinan spontan kurang bulan tanpa ketuban pecah dini, sedangkan jenis mikroorganisme pada persalinan cukup bulan tanpa ketuban pecah dini paling banyak Staphylococcus sp. dan E. coli. Terdapat perbedaan jenis mikroorganisme aerob antara persalinan spontan kurang dan cukup bulan tanpa ketuban pecah dini. Jenis-jenis mikroorganisme aerob, sesuai dengan penelitian Vatish dkk. ${ }^{17}$ mengenai jenis mikroorganisme yang didapat dari hasil isolasi pada rongga amnion wanita hamil dengan persalinan kurang bulan.

Mikroorganisme aerob yang didapatkan dari hasil kultur subjek penelitian persalinan spontan kurang dan cukup bulan tanpa ketuban pecah dini yaitu mikroorganisme aerob dengan jenis yang sama, oleh karena itu dilakukan penghitungan terhadap jumlah mikroorganisme pada kedua subjek penelitian.

Jumlah mikroorganisme rata-rata pada subjek dengan persalinan spontan kurang bulan lebih banyak dibandingkan dengan persalinan cukup bulan tanpa ketuban pecah dini. Hasil analisis menunjukkan bahwa terdapat perbedaan jumlah mikroorganisme aerob antara persalinan spontan kurang dan cukup bulan tanpa ketuban pecah dini. Penelitian ini sesuai dengan penelitian Onderdonk dkk. ${ }^{9}$

Keterbatasan penelitian ini walaupun sudah dilakukan upaya menyingkirkan faktor perancu dengan kriteria inklusi dan eksklusi, tetapi tidak seluruhnya sempurna seperti misalnya pemeriksaan laboratorium hanya diambil pada saat penderita datang untuk persalinan, sebaiknya pemeriksaan tersebut diikuti sejak kunjungan pertama. Selain itu, standar baku pemeriksaan sebaiknya diambil 
dari cairan amnion dengan cara amniosentesis is $^{15,18,19}$ dan pada penelitian ini sampel diambil dari selaput amnion pada saat proses persalinan. Terdapat hubungan bermakna persalinan spontan kurang dan cukup bulan tanpa ketuban pecah dini dengan korioamnionitis, yaitu persalinan spontan kurang bulan tanpa ketuban pecah dini diawali oleh proses infeksi dalam rahim, yaitu korioamnionitis.

Jenis-jenis mikroorganisme aerob persalinan spontan kurang dengan cukup bulan tanpa ketuban pecah dini berbeda sehingga memberikan gambaran jenis mikroorganisme aerob apa saja yang dapat memicu dan atau tidak menyebabkan persalinan kurang bulan.

Jumlah mikroorganisme lebih banyak pada persalinan spontan kurang dibandingkan dengan cukup bulan tanpa ketuban pecah dini.

Simpulan, persalinan spontan kurang bulan tanpa ketuban pecah dini disebabkan korioamnionitis yang dipengaruhi oleh jumlah mikroorganisme.

\section{Daftar Pustaka}

1. Cunningham FG, Gant NF, Leveno KJ, Gillstrap LC, Hauth JC, Wenstrom KT. William obstetric. Edisi ke-22. London: McGraw-Hill; 2006.

2. Romero R, Chaiworapongsa T. Preterm labor, intrauterine infection, and the fetal inflammatory response syndrome. NeoReviews 2002;3(5):e73-8.

3. Heni A. Perbandingan kadar progesterone serum antara persalinan kurang bulan dan cukup bulan (Tesis). Bandung: Universitas Padjadjaran; 2005.

4. Lockwood C. Risk stratification and pathological mechanism in preterm delivery. Paed Perinatal Epidemiol. 2001;15:79-89.

5. Wadhwa P, Culhane J, Virginia R. Stress, infection and preterm birth: a biobehavioral perspective. Pediatr Perinatal Epidemiol. 2001;15:17-29.

6. Krisnadi S. Penggunaan klindamisin untuk menurunkan kejadian beratbadan lahir rendah pada vaginosis bakterialis dengan atau tanpa kolonisasi streptokokus grup B dan infeksi oleh Chlamydia trachomatis [disertasi]. Bandung: Universitas Padjadjaran; 2000.

7. Hershkovits M, Erez G, Sheiner L. Comparison study between induced and spontaneous term and preterm births of small for gestational age neonates. Eur J Obstet Gynecol. 2001;97:141-6.
8. Ustun C, Kocak I, Baris S, Uzel A, Saltik F. Subclinical chorioamnionitis as an etiologic factor in preterm deliveries. Int J Gynecol Obstet. 2001;72:109-15.

9. Onderdonk AB, Lee ML, Ellice L. Quantitative microbiologic models for preterm delivery; Channing Laboratory, Department of Pathology and Medicine, Harvard Medical School. J Clin Microbiol. 2003;41(3):1073-9.

10. Yeast JD, Lu G. Biochemical markers for the prediction of preterm labor. Obstet Gynecol Clin North Am. 2005;32:369-81.

11. Elliot JP. Preterm labor in twins and highorder multiples. Obstet Gynecol Clin North Am. 2005;32:429-39.

12. Cahill DJ, Wardle PG. Bleeding and pain in early pregnancy. Dalam: James DK, Steer JK, Weiner CP, Gonik B, penyunting. High risk pregnancy: management options. Edisi ke-3. Philadelphia: Elsevier Saunders; 2006. hlm. 1881-936.

13. Romero R, Gomez R, Chaiworapongsa $\mathrm{T}$, Conoscenti G, Kim JC, Kim YK. The role of infection in preterm labour and delivery. Blackwell Science. 2001;15(2):41-56.

14. Klein LL, Gibbs RS. Infection and preterm birth. Obstet Gynecol Clin North Am. 2005;32:397-410.

15. Gonzales LF, Chariworapongsa T, Romero $\mathrm{R}$. Intrauterine infection, preterm parturition $\&$ the fetal inflammatory response syndrome. Dalam: James D, Steer P, Weiner C, Gonik $\mathrm{B}$, penyunting. High risk pregnancy: management option. Edisi ke-3. Philadelphia: Elsevier-Saunders; 2006. hlm. 583-665.

16. Hillier SL. Complications associated with bacterial vaginosis [diunduh 31 Oktober 2006]. Tersedia dari: http://www.baylorcme. org/vaginosis/ pres pres.html.

17. Vatish M, Groom K, Bennet P, Thornton S. Management of threatened preterm labor. Dalam: Norman J, Greer I, penyunting. Preterm labor: managing risk in clinical practice. Edisi ke-1. Cambridge: Cambridge University Press; 2005. hlm. 191-209.

18 Amon E, Myles TD. Preterm labor. Dalam: Reece EA, Hobbins JC, penyunting. Clinical obstetrics The fetus \& mother. Edisi ke3. USA: Blackwell Publishing; 2008. hlm. 1085-118.

19. Tucker J, McGuire E. ABC of preterm birth. Epidemiology of preterm birth. Clinical review. BMJ. 2004;329:675-8. 